удк 378

Микола Федорець

Державний заклад «Південноукраїнський національний педагогічний університет імені К. Д. Ушинського» ORCID ID 0000-0001-6243-4208

Го Цзюнь

Державний заклад «Південноукраїнський національний педагогічний університет імені К. Д. Ушинського»

ORCID ID 0000-0001-5855-0441

DOI 10.24139/2312-5993/2020.08/485-495

\title{
АКТУАЛЬНІ ПИТАННЯ ПІДГОТОВКИ МАЙБУТНІХ УЧИТЕЛІВ ДО ФОРМУВАННЯ МУЗИЧНОЇ КУЛЬТУРИ СУЧАСНИХ ШКОЛЯРІВ
}

Дана стаття присвячена актуальним питанням підготовки майбутніх учителів музичного мистецтва України та Китаю для продуктивної праці $з$ сучасними школярами, зокрема, формуванню в учнів належної музичної культури в умовах інтенсивного розвитку інформаційного суспільства. У процесі підготовки статті використано теоретичні й емпіричні методи дослідження, а саме - аналіз певної літератури, узагальнення, педагогічне спостереження.

у роботі надано сутність понять культура, художня культура та музична культура, а також наведено взаємозвязок $і$ взаємозалежність даних явищ. Приведено структура френомену музичної культури. Підкреслено актуальність формування музичної культури школярів як частини духовного життя особистості з урахуванням нових можливостей, які надає інформачійне суспільство.

Ключові слова: музична культура, музична культура сучасних школярів, підготовка майбутніх учителі музичного мистецтва до формування музичної культури сучасних школярів.

Постановка проблеми. Світовою практикою доведено, що рівень музичної культури особистості залежить, у першу чергу, від своєчасності та якості музичного виховання, яке відбулося в дитинстві. Дослідження канадських учених показують, що основи цієї культури закладаються в дошкільному віці та стабілізується як стійка система цінностей, смаків, музичних вподобань, у шкільні роки (McCain \& Mustard, 1999). Відомо, що масове формування музичної культури школярів має бути вирішене переважно завдяки організації музичного виховання, яке здійснюють учителі музичного мистецтва в закладах загальної середньої освіти.

Як свідчать дослідження, в останні роки в Україні загострилася проблема якісної підготовки майбутніх учителів музичного мистецтва в контексті реалізації Концепції Нової української школи (НУШ), що вимагає від педагогів уміння формування в учнів низки ключових компетентностей, зокрема загальноосвітньої грамотності. Практика показує, що майбутні 
вчителі музичного мистецтва можуть оволодіти високим рівнем фахових компетентностей: вокально-виконавських, фортепіанних, теоретичних тощо, але бути недостатньо підготовленими до формування відповідних якостей та музичної культури у школярів. Проблема підсилюється ще тим, що години уроку музичного мистецтва або скорочуються в українських школах, або набувають іншої форми, стають більш інтегрованими (Реброва та Пань Сінюй, 2018). Крім того, українські педагоги-музиканти, на наш погляд, отримують недостатню психолого-педагогічну підготовку, яка необхідна для продуктивної роботи із сучасними школярами, віднесеними до покоління Альфа, та їх батьками.

У КНР сучасна шкільна музично-освітня система почала формуватися 3 80-х років XX століття, коли було прийнято рішення про проведення обов'язкових уроків музики для школярів. Зростання ролі загальної музичної освіти й музичного виховання учнів зумовило необхідність відновлення діяльності як існуючих раніше закладів освіти, так і відкриття нових закладів, що забезпечують професійну підготовку майбутніх учителів музичного мистецтва (Джоу Юнь, 2017). у 2001 році Міністерство освіти КНР оприлюднило Новий стандарт музичних дисциплін обов'язкової освіти, що стало важливим кроком у реформуванні загальної музичної освіти та приєднанні до світового освітнього простору. Новий стандарт передбачає поєднання музичної підготовки з іншими мистецтвами та науками, збагачення змісту музичного навчання новими цікавими формами й інформацією (Чан Веньцзін, 2011). Помітно поширилася підготовка майбутніх учителів-музикантів як у самому Китаї, так і навчання китайських здобувачів освіти в інших країнах, зокрема в Україні.

Однак, незважаючи на престиж учительської професії, у Китаї спостерігається суттєва нестача учителів музики, що пов'язано значною мірою з економічним становищем і ситуацією в кожному конкретному регіоні країни, а також із місцем розташування самих шкіл - у місті або сільській місцевості, у розвиненому або відсталому районі (Ван Юечжи та Чжоу Чжень Юй, 2017).

Щодо підготовки майбутніх учителів музичного мистецтва з Китаю, які навчаються в закладах освіти України, то вони взагалі слабко зорієнтовані на викладання музичного мистецтва в закладах загальної середньої освіти. Більшість із них умотивовані або на творче виконавське самовираження, або на викладання популярних у Китаї вокалу та гри на фортепіано. 3 одного боку, у Китаї існують свої музичні традиції, які підтримуються державною політикою; з іншого боку, - відкритість 
глобалізаційного простору, культурна мобільність школярів та студентів розширює їхні уявлення про сучасну музику (Реброва та Пань Сінюй, 2018).

Таким чином, проблема підготовки майбутніх учителів до формування музичної культури школярів наразі $\epsilon$ актуальною як для України, так і для Китаю. Аналіз літератури та спостереження за роботою українських і китайських закладів загальної середньої освіти свідчать, що у процесі музичного виховання сучасних школярів склалися певні суперечності: між об'єктивної необхідністю підвищення музичної культури школярів останнього покоління й застарілими, малоефективними засобами та методиками ї̈ формування; між необхідністю набуття школярами загальнокультурної грамотності в якості ключової компетентності та предметних (художньо-музичних) компетентностей як показника музичної культури і недостатньою підготовленістю учителів, яким доручена ця важлива місія.

Мета статті полягає в аналізі та узагальненні досліджень українських та китайських науковців щодо сутності феномену музичної культури та умов підготовки майбутніх учителів музичного мистецтва до їі формування в сучасних школярів.

Методи дослідження. Для реалізації мети даної роботи використано комплекс теоретичних та емпіричних методів: аналіз та узагальнення українських і китайських наукових джерел; метод порівняння; метод педагогічного спостереження.

Виклад основного матеріалу. Огляд філософських, соціологічних, психолого-педагогічних, культурологічних, мистецько-музикознавчих, музично-педагогічних джерел кінця XX та протягом останніх років XXI століття засвідчує, що питанням підготовки майбутніх учителів музичного мистецтва 3 метою модернізації загальної музичної освіти, дослідження феномену музичної культури і проблеми їі формування у школярів знайшли певне віддзеркалення в працях науковців Украйни, Китаю та інших країн світу.

Культура - це сукупність матеріальних і духовних цінностей, створених людством протягом його історії (Словник Української Мови, 1970-1980, т. 4, с. 394). Найбільш відомим є розподіл культури на матеріальну й духовну, що відповідає основним напрямам суспільного виробництва та творчої діяльності. Духовну культуру поділяють на наукову, естетичну, художню тощо. Учені виокремлюють також певні галузі художньої культури, пов'язані з різними видами мистецтва, у тому числі й музичну культуру. У наукової літературі музична культура, у свою чергу, представлена поняттями «музична культура суспільства», «музична культура особистості» тощо. 
Таким чином, музична культура розглядається в наукової літературі як вид художньої культури і частина духовної культури людства; як складна система, елементами якої $\epsilon$, з одного боку, види музичної діяльності (створення музики, виконання музики, сприймання музики, музичноритмічні рухи під музику тощо) та музичні цінності, а з іншого боку - типи, жанри і стилі музики, що належать різним епохам, національним та світовим культурам (Негребецька, 2012). Музичну культуру особистості можна розглядати в кількох аспектах, а саме: як результат впливу музичної культури суспільства, як умову подальшого художньо-творчого розвитку особистості, як результат специфічної духовно-практичної діяльності людей і спосіб існування та функціонування їх музичної свідомості, як частину загальної духовної культури особистості, як досвід особистості у сфері музичного мистецтва, як сукупність специфічних способів музичної діяльності людей (Негребецька, 2012).

Ю. Алієв у контексті художньої дидактики визначає мету музичної освіти як «формування музичної культури учнів, що передбачає отримання позитивного соціально-художнього досвіду через сприймання та опанування мистецтва» (Алієв, 2000, с. 21-22).

Отже, поняття «музична культура» відіграє суттєву роль у визначенні музичної освіти як творчого складника в змісті. Музична культура суспільства в музичній естетиці визначається як єдність музики та ії соціальних функцій, тобто система, до якої входять (за А. Сохором): музичні цінності (створені або збережені в цьому суспільстві); усі види діяльності (щодо створення, збереження, відтворення, поширення, сприймання та використання музичних цінностей); усі суб'єкти такого роду діяльності разом із їхніми знаннями, навичками та іншими якостями, що забезпечують її успіх (Сохор, 1980, с. 62).

Л. Школяр і О. Критська вважають елементами музичної культури три компоненти: музичний досвід, музичну грамотність та музично-творчий розвиток школярів. Інтегральним показником сформованості музичної культури виступає музично-творчий розвиток як синтез музичного досвіду та музичної грамотності (Беземчук, 2009).

Проблема якісної підготовки майбутніх учителів музичного мистецтва, здатних до реального формування музичної культури школярів та достатньо мотивованих до виконання цієї відповідальної діяльності, $€$ актуальною в українській і китайській науковій та науково-методичній літературі. Багато авторів підкреслюють, що традиційна підготовка педагогів-музикантів не відповідає ані новим реаліям інформаційного суспільства, що швидко 
розвивається, ані очікуванням людей. Українська Концепція НУШ і китайський Новий стандарт музичних дисциплін обов'язкової освіти (Чан Вэньцзін, 2011) орієнтують всю систему музично-педагогічної освіти на підготовку учителів нового покоління, здатних до продуктивної праці 3 сучасними школярами, віднесеними до покоління Альфа. Як відомо, ці діти, народжені в епоху інтернету, істотно відрізняються від їх батьків і самих педагогів своїми психо-фізіологічним і психологічним характеристиками, художніми смаками і вподобаннями, а головне - особливостями сприйняття будь-якої інформації, у тому числі й творів музичного мистецтва.

Підготовка майбутніх бакалаврів і магістрів в Україні повинна відбуватися з системним використанням не лише традиційних музичнопедагогічних методів, а, у першу чергу, сучасних аудіовізуальних та мультимедійних технологій, без яких сьогодні неможливо підготувати їх до формування музичної культури школярів останнього покоління.

Слід зазначити, що в китайських професійних музично-педагогічних закладах вже багато років упроваджуються технології мистецької інноватики, у тому числі з використанням супутників зв'язку, за допомогою яких транслюють спеціальні телевізійні передачі у вигляді навчальних і педагогічних програм. Починаючи з 1990-х років, на музичних факультетах багатьох педагогічних вишів Китаю змінилися форми й методи викладання. Головні зміни пов'язані з комп'ютеризацією навчання та введенням нових дисциплін. У зв'язку з цим можна стверджувати, що реформа вищої музичнопедагогічної освіти розвивається за двома основними напрямами: оволодіння комп'ютерними технологіями та освоєння музично-теоретичних дисциплін за допомогою цих технологій (Ван Юечжи та Чжоу Чжень Юй, 2017).

На музичному факультеті Пекінського педагогічного університету введено такі дисципліни, як «Музична творчість за допомогою комп'ютера», «Методика навчання гри на роялі», «Методика навчання вокальної майстерності». На музичному факультеті Наньцзінського педагогічного університету сьогодні викладають дисципліну «Основи комп'ютерної композиції»; у Харбінському педагогічному університеті - «Музичну психологію» i «Слухання китайської та зарубіжної сучасної музики»; у Сінаньскому педагогічному університеті - «Методику написання дисертації 3 музики»і «Спеціальну англійську мову»; у Фуцзяньському педагогічному університеті - «Вступ до народної творчості різних країн та народів»; у Чжецзянському педагогічному університеті - «Вступ до музичної культури» і «Твір дисертації з музики»; у Нейменгуському педагогічному університеті «Музичне виховання» та «Електронні музичні інструменти»; у Сичуаньському 
музичному інституті - «Педагогічні здібності та майстерність»; у Сюйчжоуському педагогічному університеті - «Налаштування рояля» та «Звукова техніка» (Хуан Сяньюй, 2012).

Проте, проблема підготовки майбутніх учителів до формування сталої музичної культури школярів у Китаї, як і в Україні, залишається невирішеною. Одною з причин такої ситуації є використання в процесі роботи з майбутніми педагогами малопродуктивних методів, у тому числі застарілих методик аналізу музичних творів під час лекційних та практичних занять.

Так, відомий китайський науковець Ду Чень стверджує, що багато викладачів переважно зосереджуються лише на формуванні теоретичних знань. Музика не завжди знаходить емоційний відгук у студентів. Часто вони не розуміють сенс музичних творів і, таким чином, відчувають нестачу в естетичному сприйнятті музики. Таке навчання не може принести духовного задоволення майбутнім учителям та не сприяє їх музично-естетичному розвитку. Звернення уваги на формування певного музично-естетичного досвіду в процесі навчання допоможе здобувачам освіти відчути красу музики, пробудити бажання самостійно займатися музикою й цінувати музичне мистецтво. Такий досвід допоможе їм у майбутньому навчити школярів слухати музику, розуміти її та насолоджуватися нею (Ду Чень, 2010).

У чому ще полягає підготовка майбутніх учителів музичного мистецтва до продуктивної роботи з сучасними школярами?

Багато педагогів знають, що одночасне поєднання зорових та слухових образів у роботі зі школярами покоління Альфа не тільки значно підвищує ефективність сприймання та засвоєння будь-якої навчальної інформації, але й привносить в освітній процес позитивну емоційну складову. Спостереження демонструють, що візуалізація процесу виконання музичних творів, особливо музично-драматичних (оперних, балетних) вистав, концертів тощо у відео форматі $€$ провідним засобом, яким потрібно користуватися всім учителям музичного мистецтва під час уроків. Такій підхід допомагає довше утримувати увагу учнів, пробуджує в сучасних школярів живий інтерес до музичного мистецтва, формує гарний художній смак, що і $\epsilon$ головними шляхами формування справжньої музичної культури.

Практикуючі вчителі музичного мистецтва зазначають, що актуальність застосування продуктивних інноваційних освітніх технологій, у першу чергу аудіовізуальних і мультимедійних, посилюється тим, що найбільше зацікавлення серед школярів викликає сам факт використання таких технологій на уроках. Зокрема, під час «слухання» музики на уроці відбувається відтворення не тільки звуку, а й відеоряду, створюється 
«ефект присутності», передається крупним планом «живе» виконання музичного твору, що дозволяє спостерігати саме специфіку процесу виконання музики (Федорець, 2016).

Відомо також, що формування достатньої музичної культури лише зусиллями педагогів не принесе бажаних результатів. У даному зв'язку слід підкреслити, що сьогоднішні бакалаври і магістри слабо підготовлені до роботи з батьками учнів у контексті нового принципу педагогіки партнерства НУШ і недостатньо мотивовані для цієї роботи.

Системне використання традиційних фахових (музично-педагогічних) методик, інтегрованих із сучасними технологіями мистецької інноватики, вимагає демократичного, гнучкого управляння освітнім процесом, дбайливого й обережного ставлення до особистості учнів. Так, управління освітньою діяльністю згідно з Концепцією НУШ передбачає наявність у педагогічному процесі трьох гармонійно узгоджених суб'єктів: учителів, учнів, батьків. Стосунки цих суб'єктів побудовані на запровадженні вище вказаного нового принципу педагогіки партнерства, що ґрунтується на засадах співпраці та взаємної поваги.

Спостереження показують, що в освітянської спільноті росте розуміння, що найважливішим викликом часу є реалізація вимог Концепції НУШ, які пов'язані з необхідністю модернізації всього освітнього процесу в школі, упровадженням демократичного, гнучкого управління освітнім процесом та використанням у роботі зі школярами інноваційних продуктивних освітніх технологій; що для формування достатньої музичної культури сьогоднішніх школярів необхідно набуття ними ключових та предметних (художньо-музичних) компетентностей, у тому числі й завдяки впровадженню нового принципу педагогіки партнерства вчителів, учнів та їх батьків, а також створення належних матеріально-освітніх умов для використання даних інноваційних продуктивних технологій, зокрема для максимальної візуалізації навчальної інформації 3 урахуванням особливостей сприйняття її дітьми покоління Альфа.

3 бесід із учителями та батьками учнів можна зробити висновок, що якісна підготовка вчителів музичного мистецтва багато в чому залежить від оволодіння майбутніми бакалаврами та магістрами не тільки традиційними музично-педагогічними методиками, а й від уміння професійно використовувати інноваційні продуктивні загально-педагогічні технології. У першу чергу, йдеться про ігрові, аудіовізуальні й мультимедійні технології. Окрім того, успіх музичного виховання, а разом із тим і формування достатньої музичної культури школярів залежить від уміння педагогів 
ефективно співпрацювати з колегами - учителями 3 інших навчальних предметів і з батьками учнів - головними замовниками шкільної освіти.

Таким чином, у змістовому та методико-технологічному аспекті підготовки майбутніх учителів музичного мистецтва назріла необхідність у суттєвих змінах. Йдеться не тільки про посилення фахового (музичнопедагогічного) блоку навчання бакалаврів і магістрів. Потрібна модернізація всього психолого-педагогічного блоку підготовки майбутніх учителів музичного мистецтва, яка сьогодні не відповідає викликам часу і вимогам Концепції НУШ у зв'язку з масовим приходом в школи дітей покоління Альфа. Особливий аспект майбутньої модернізації - суттєві зміни у викладанні методики музичного виховання як у музично-педагогічному, так і в загальнопедагогічному аспектах, а також професійна підготовка майбутніх учителів до ефективної спільної роботи з батьками учнів у контексті запровадження нового принципу педагогіки партнерства. Модернізація також повинна торкнутися всього комплексу організації виробничої (педагогічної) практики здобувачів вищої освіти за першим (бакалаврським) рівнем.

Подібна модернізація, на наш погляд, повинна відбутися також на курсах підвищення кваліфікації працюючих учителів музичного мистецтва в установах післядипломної освіти.

Особливої уваги потребує модернізація навчально-матеріальної бази, як із викладання методики музичного виховання на відповідних факультетах, так і для організації виробничої (педагогічної) практики в базових закладах середньої освіти. Йдеться про оснащення університетських навчальних аудиторій та шкільних кабінетів музичного мистецтва якісними технічними засобами, які дозволяють широке використання аудіовізуальних і мультимедійних технології в освітньому процесі.

Висновки. У результаті проведеного дослідження шляхом аналізу, порівняння та узагальнення українських і китайських наукових джерел, а також педагогічного спостереження за роботою закладів загальної середньої освіти України та Китаю, можна зробити такі висновки: питання якісної підготовки майбутніх учителів до формування в сучасних школярів музичної культури є надзвичайно важливим завданням для відповідних українських і китайських професійних закладів освіти; придбання сучасними школярами достатньої музичної культури в умовах розвитку інформаційного суспільства $\epsilon$ головним показником ефективності музичного виховання та критерієм продуктивності всієї системи загальної музичної освіти; проблема підготовки майбутніх педагогів-музикантів до продуктивної роботи з сучасними школярами, віднесеними до покоління Альфа, наполегливо потребує 
подальшого дослідження та детальної розробки особливо в напрямах: більш ефективної психолого-педагогічної підготовки здобувачів освіти, оволодіння ними технологіями мистецької інноватики (аудіовізуальними, мультимедійними тощо), формування в майбутніх бакалаврів та магістрів уміння донести до школярів красоту класичної, народної та сучасної (легкої) музики; прищеплення учням художнього смаку та «імунітету» проти вподобання неякісного музичного контенту, продуктивної роботи з батьками школярів в напрямі формування в їхніх дітей певної музичної культури.

\section{ЛІТЕРАТУРА}

Алиев, Ю. Б. (2000). Настольная книга школьного учителя-музыканта. Москва: ВЛАДОС (Aliiev, Yu. B. (2000). Handbook of a school musician teacher. M oscow: VLADOS).

Беземчук, Л. В. (2009). Формування музичної культури школярів як сучасна проблема художньої дидактики. Вісник Луганського національного університету імені Tараса Шевченка (Bezemchuk, L. V. (2009). Formation of schoolchildren's musical culture as a modern problem of artistic didactics. Bulletin of Luhansk Taras Shevchenko National University). Retrieved from: http:// www.stattionline.org.ua/pedagog/104/ 17662-formuvannya-muzichnoï-kulturishkolyariv-yak-suchasna-problema-xudozhnoï-didaktiki.html.

Ван Юечжи, Чжоу Чжень Юй (2017). Особливості підготовки вчителів музики в КНР у період після "Культурної револючії". Харків (Wang Yuezhi, Zhou Zhen Yu (2017). Features of music teachers training in China in the period after the "Cultural Revolution". Kharkiv). Retrieved from: http://www.pedagogy-journal.kpu.zp.ua/55-2017.

Джоу Юнь (2017). Історичні передумови та сучасні тенденції розвитку музично-педагогічної освіти в КНР. Педагогіка фрормування творчої особистості у вищій $i$ загальноосвітній школах, Вип. 55 (108) (Zhou Yun (2017). Historical preconditions and modern trends of music-pedagogical education development in the People's Republic of China. Pedagogy of creative personality formation in higher and secondary schools, Vol. 55 (108)). Retrieved from: http:// pedagogy-journal.kpu.zp.ua/archive/2017/55/4.pdf.

Ду Чень (2010). Осмислення музичної естетики в контексті «Філософії музичної освіти» Реймера. Ченду: Південно-Західний університет Цзяотун (Du Chen (2010). Understanding musical aesthetics in the context of Reimer's "Philosophy of Music Education". Chengdu: Southwestern Jiaotong University). Retrieved from: https://www.doc88.com/p-8159201726528.html.

Негребецька, О. (2012). Ціннісний контекст музичної культури. Наукові записки Кіровоградського державного педагогічного університету імені В. Винниченка. Сер.: Педагогічні науки, Вип. 107 (2), 38-45 (Nehrebetska, 0. (2012). Value context of music culture. Scientific notes of Kirovohrad State Pedagogical University named after V. Vynnychenko. Series: Pedagogical Sciences, Vol. 107 (2), 38-45). Retrieved from: http://nbuv.gov.ua/UJRN/Nz_p 2012 107\%282\%29_8.

Словник української мови: в $11 \mathrm{~mm}$. / АН УРСР. Інститут мовознавства; за ред. І. К. Білодіда. Київ: Наукова думка. 1970-1980. Т. 4. С. 394 (Dictionary of the Ukrainian language: in 11 vols. / USSR Academy of Sciences. Institute of Linguistics; ed. by I. K. Bilodid. Kyiv: Scientific opinion. 1970-1980. Vol. 4. S. 394).

Coхор, А. Н. (1980). Музыкальная культура общества. Вопр. социологии и эстетики музики в 3 m. T. 1. Ленінград - Москва: Музыка (Sokhor, A. N. (1980). Musical culture of society. Questions of Sociology and Aesthetics of Music in 3 vols. Vol. 1. Leningrad - Moscow: Music). 
Реброва, О. Є., Пань Сінюй (2018). Сутність та структура підготовленості бакалаврів музичного мистецтва до формування аудіальної культури школярів. Науковий вісник Південноукраїнського національного педагогічного університету ім. $K$. Д. Уиинського. Педагогічні науки, 4, 68-73 (Rebrova, O. Ye, Pan Sinyui (2018). The essence and structure of the preparation of bachelors of musical art for the formation of audio culture of schoolchildren. Scientific Bulletin of the South Ukrainian National Pedagogical University named after K. D. Ushynsky. Pedagogical Sciences, 4, 68-73). Retrieved from: http://nbuv.gov.ua/UJRN/Nvpupupp 2018 414.

Федорець, М. О. (2016). Урок музичного мистецтва в сучасній школі: проектування, реалізація, аналіз (методичні рекомендації). Мистецтво в школі, 3, 4 (Fedorets, M. O. (2016). Music art lesson in a modern school: design, implementation, analysis (guidelines). Art at school, 3, 4).

Хуан Сяньюй (2012). Система музыкального образования в Китае. Вестник СанктПетербуржского государственного университета культуры и искусств, 2 (11), 155-159 (Huang Xiangyu (2012). The system of music education in China. Bulletin of St. Petersburg State University of Culture and Arts, 2 (11), 155-159).

Чан Веньцзін. Новий стандарт музики. (Китайською мовою) (Chan Wenjing. A new standard of music. (In Chinese)). Retrieved from: http://www.chinadmd.com/file/pvoooxppwzpous6xtvvsisst 1.html.

M ustard, J. F. and M cCain, M. N. (1999). Reversing the Real Brain Drain: Early Years Study: Final Report. Canadian Institute for Advanced Research. Government of Ontario.

\section{PEЗЮME}

Федорец Николай, Го Цзюнь. Актуальные вопросы подготовки будущих учителей к формированию музыкальной культуры современных школьников.

Данная статья посвящена актуальным вопросам подготовки будущих учителей музыкального искусства Украины и Китая для производительного труда с современными школьниками, в частности, формированию у учащихся надлежащей музыкальной культуры в условиях интенсивного развития информационного общества. В процессе подготовки статьи использованы теоретические и эмпирические методы исследования, а именно - анализ определенной литературы, обобщение, педагогическое наблюдение.

В работе предоставлена сущность понятий культура, художественная культура и музыкальная культура, а также приведена взаимосвязь и взаимозависимость данных явлений. Приведена структура феномена музыкальной культуры. Подчеркнута актуальность формирования музыкальной культуры школьников как части духовной жизни личности с учетом новых возможностей, которые предоставляет информационное общество.

Ключевые слова: музыкальная культура, музыкальная культура современных школьников, подготовка будущих учителя музыкального искусства к формированию музыкальной культуры современных школьников.

\section{SUMMARY}

Fedorets Mykola, Guo Jun. Topical issues of future musical art teachers training for the formation of modern schoolchildren's musical culture.

The article is devoted to topical issues of training future musical art teachers in Ukraine and China for productive work with modern students, in particular, formation of students' proper musical culture in the intensive development of the information society. In the process of preparing the article, theoretical and empirical research methods were used, namely, analysis of scientific literature, generalization, and pedagogical observation. 
The paper presents the essence of the concepts of culture, art culture and music culture, as well as the relationship and interdependence of these phenomena. The structure of the phenomenon of musical culture is given. The urgency of forming the musical culture of schoolchildren as a part of the spiritual life of the individual is emphasized, taking into account new opportunities provided by the information society. The concept of "training future musical art teachers to work with modern students" is defined. The research of Ukrainian and Chinese scientists is presented, which highlighted the problem of training future musical art teachers for the successful formation of musical culture of schoolchildren, as a criterion for the quality of music education and a kind of indicator of students' acquisition of general cultural literacy. The peculiarities of music perception by schoolchildren of the last generation, marked in the literature as the Alpha generation, are given. Some contradictions have been revealed, which have become more acute during the preparation of future bachelors and masters and hinder the process of forming the musical culture of modern schoolchildren.

It is concluded that modernization of future teachers training is a necessary condition of increasing efficiency of teaching students and forming their proper musical culture.

Key words musical culture, musical culture of modern schoolchildren, preparation of future musical art teachers for the formation of musical culture of modern schoolchildren.

\title{
удк 378.016(510)
}

\author{
Чжан Лянхун \\ Сумський державний педагогічний \\ університет імені А. С. Макаренка \\ ORCID ID 0000-0002-9688-7560
}

DOI 10.24139/2312-5993/2020.08/495-504

\section{ПІДГОТОВКА ФАХІВЦІВ ВОКАЛЬНОГО МИСТЕЦТВА В СИСТЕМІ ВИЩОЇ МУЗИЧНОӦ ОСВІТИ КИТАЮ: МЕТОДОЛОГІЧНИЙ АСПЕКТ}

у статті з'ясовано методологічні підходи до підготовки фрахівців вокального мистецтва в системі вищої музичної освіти Китаю. На підставі аналізу теоретикометодологічних засад підготовки фрахівців вокального мистецтва в системі вищої музичної освіти Китаю виокремлено методологічні підходи: академічний; особистісно орієнтований; культурологічний. Доведено, що важливими концептуальними ідеями, які покладено в основу професійної підготовки вокалістів у системі вищої музичної освіти Китаю, є: опора на національні виконавські й педагогічні традиції в поєднанні із запозиченням досвіду інших країн у чій срері та максимальне використання можливостей культурного середовища в процесі підготовки вокалістів.

Ключові слова: вокальне мистецтво, фахівці вокального мистецтва, підготовка фахівців вокального мистецтва, методологічні підходи, вища музична освіта Китаю.

Постановка проблеми. Сучасний розвиток мистецької освіти в Китаї характеризується акцентуванням уваги на розв'язанні основних завдань мистецьких закладів вищої освіти країни. Діяльність таких закладів спрямована на збереження й поширення національних традицій та їх 